\title{
Anticoagulation in Patients with End-Stage Renal Disease and Atrial Fibrillation: Confusion, Concerns and Consequences
}

\author{
Narender Goel, ${ }^{\mathrm{a}, \mathrm{b}, \mathrm{c}}$ Deepika Jain, ${ }^{\mathrm{a}, \mathrm{b}, \mathrm{c}}$ Danny B. Haddad, ${ }^{\mathrm{a}, \mathrm{b}, \mathrm{c}}$ Divya Shanbhogue ${ }^{\mathrm{d}}$ \\ ${ }^{a}$ New Jersey Kidney Care, Jersey, NJ, USA \\ ${ }^{b}$ Division of Nephrology, CarePoint Health Hospitals, Jersey, NJ, USA \\ 'Division of Nephrology, Jersey City Medical Center, Jersey, NJ, USA \\ ${ }^{\mathrm{D} D}$ Department of Medicine, Jersey City Medical Center, Jersey, NJ, USA
}

\begin{abstract}
End-stage renal disease (ESRD) patients have a higher prevalence of diabetes mellitus, hypertension, congestive heart failure and advanced age, along with an increased incidence of non-valvular atrial fibrillation (AF), thereby increasing the risk for cerebrovascular accidents. Systemic anticoagulation is therefore recommended in patients with ESRD with AF to reduce the risk and complications from thromboembolism. Paradoxically, these patients are at an increased risk of bleeding due to great degree of platelet dysfunction and impaired interaction between platelet and endothelium. Currently, $\mathrm{CHA}_{2} \mathrm{DS}_{2}$-VASc and Hypertension, Abnormal liver/kidney function, Stroke, Bleeding, Labile INR, Elderly, Drugs or alcohol (HAS-BLED) are the recommended models for stroke risk stratification and bleeding risk assessment in patients with AF. There is conflicting data regarding benefits and risks of medications such as antiplatelet agents, warfarin and direct oral anticoagulants in ESRD patients with AF. Moreover, there is no randomized controlled trial data to guide the clinical decision making. Hence, a multi-disciplinary approach with annual re-evaluation of treatment goals and risk-benefit assessment has been recommended. In this article, we review the current recommendations with risks and benefits of anticoagulation in patients with ESRD with AF.
\end{abstract}

Correspondence: Narender Goel New Jersey Kidney Care, 26 Greenville Avenue, Jersey, NJ 07305, USA

Tel: +1-201-333-8222

Fax: +1-201-333-0095

E-mail:drnarendergoel@gmail.com https://orcid.org/0000-0001-67286013

Received: May 19, 2019

Revised: July 22, 2020

Accepted: July 27, 2020

Keywords Kidney failure, chronic; Atrial fibrillation; Anticoagulants; Stroke

\section{Introduction}

Over the years, number of patients with end-stage renal disease (ESRD) have been steadily increasing. Even though, the mortality rates have decreased, it still remains high (165 per 1,000 patient-years). ${ }^{1}$ Cardiovascular (CV) causes accounts for $48 \%$ of all deaths among ESRD patients. In particular, there is an increased risk of atrial fibrillation (AF) and thromboembolism such as deep vein thrombosis, pulmonary embolism, transient ischemic attack (TIA) and cerebrovascular accident (CVA). ${ }^{2}$ In a study of 40 hemodialysis (HD) patients, onset of AF was noted to be more often on the day of HD and specifically during the HD treatment, suggesting $H D$ as a trigger for AF in itself. ${ }^{3}$ Larger left atrium, higher systolic blood pressure, and increased age were additional risk factors for $\mathrm{AF}^{3,4}$ In addition to $A F$, risk of stroke (event rate of 5.61 per 100 person years) in ESRD patients is greatly increased as compared to those without renal impairment (event rate of 3.61 per 100 person years), ${ }^{5}$ which is very concerning due to the already increased CV mortality among ESRD patients.

Systemic anticoagulation is routinely recommended for CVA/ TIA risk reduction in patients with $A F_{1}$ with $\mathrm{CHA}_{2} \mathrm{DS}_{2}$-VASc risk 
factors. But, the case is not the same with patients with the kidney disease, as there have been concerns of increased risk of bleeding with the use of systemic anticoagulants in the ESRD population. ${ }^{5}$ As noted in the United States Renal Data System (USRDS) database, in 2016, only $32.5 \%$ of HD, $31.5 \%$ of peritoneal dialysis (PD) and $32.6 \%$ of transplants patients with $\mathrm{AF}$ were prescribed warfarin and $9.4 \%$ of $\mathrm{HD}, 9.4 \%$ of $\mathrm{PD}$ and $17.8 \%$ of transplant patients were given direct oral anticoagulant (DOACs). ${ }^{2}$ As per the Kidney Disease/Improving Global Outcome (KDIGO), there is a lack of high quality evidence to recommend warfarin or single or dual antiplatelet agents for stroke prevention in ESRD with AF and to reduce bleeding risk, low dose apixaban (2.5 $\mathrm{mg}$ orally twice a day) or rivaroxaban (15 mg once a day) may be considered. However, a team based and multi-disciplinary approach with annual re-evaluation of treatment goals and risk-benefit assessment was recommended. ${ }^{6}$

Hence, widespread sense of confusion is prevailing in the medical community regarding systemic anticoagulation in ESRD patients with AF (Figure 1). In a recent multinational survey of cardiologist and nephrologists, substantial intra and inter specialty heterogeneity was noted in terms of use, dosing and monitoring of oral anticoagulant in patients with the chronic kidney disease (CKD). ${ }^{7}$ In this review, we would like to discuss the current evidence and pros/cons of systemic antico- agulation in a particularly vulnerable patient population with the condition of ESRD.

\section{Epidemiology of AF and CVA in ESRD}

As per the USRDS, prevalence of AF in HD, PD and transplant patients were reported as $19.6 \%, 14.1 \%$, and $10.9 \%$, respectively. Prevalence of AF in HD patients showed considerable differences among different age groups as $5.5 \%$ in age 22 to 44 years, which dramatically increased to $24.6 \%$ in 65 to 74 years and $33.2 \%$ in $>74$ years of age group. Similar patterns were observed in PD and transplant patients as well. ${ }^{2}$ In the most recent analysis of 117,023 dialysis patients from Taiwan, patients on HD and PD had an incidence of AF as 8.8 and 7.8 events per 1,000 person-years, respectively. ${ }^{8} \mathrm{AF}$ is a known risk factor for stroke. In a Canadian cohort of 5,502 HD patients with $A F$, authors found incidence rate of stroke as 26.7 per 1,000 patient-years. ${ }^{9}$ Race and ethnicity have also been shown to have an impact on risk of CVA in the presence of ESRD and AF. In a cohort of 56,587 ESRD patients on HD; Blacks (hazard ratio [HR], 1.13; 95\% confidence interval [Cl], 1.02 to 1.24), Hispanics ( $\mathrm{HR}, 1.15 ; 95 \% \mathrm{Cl}, 1.01$ to 1.30), and Asians ( $\mathrm{HR}, 1.16 ; 95 \% \mathrm{Cl}, 1.02$ to 1.35$)$ were all at the increased risk of stroke as compared to whites. ${ }^{10}$ Risk of ischemic stroke is much higher than the risk of hemorrhagic stroke in

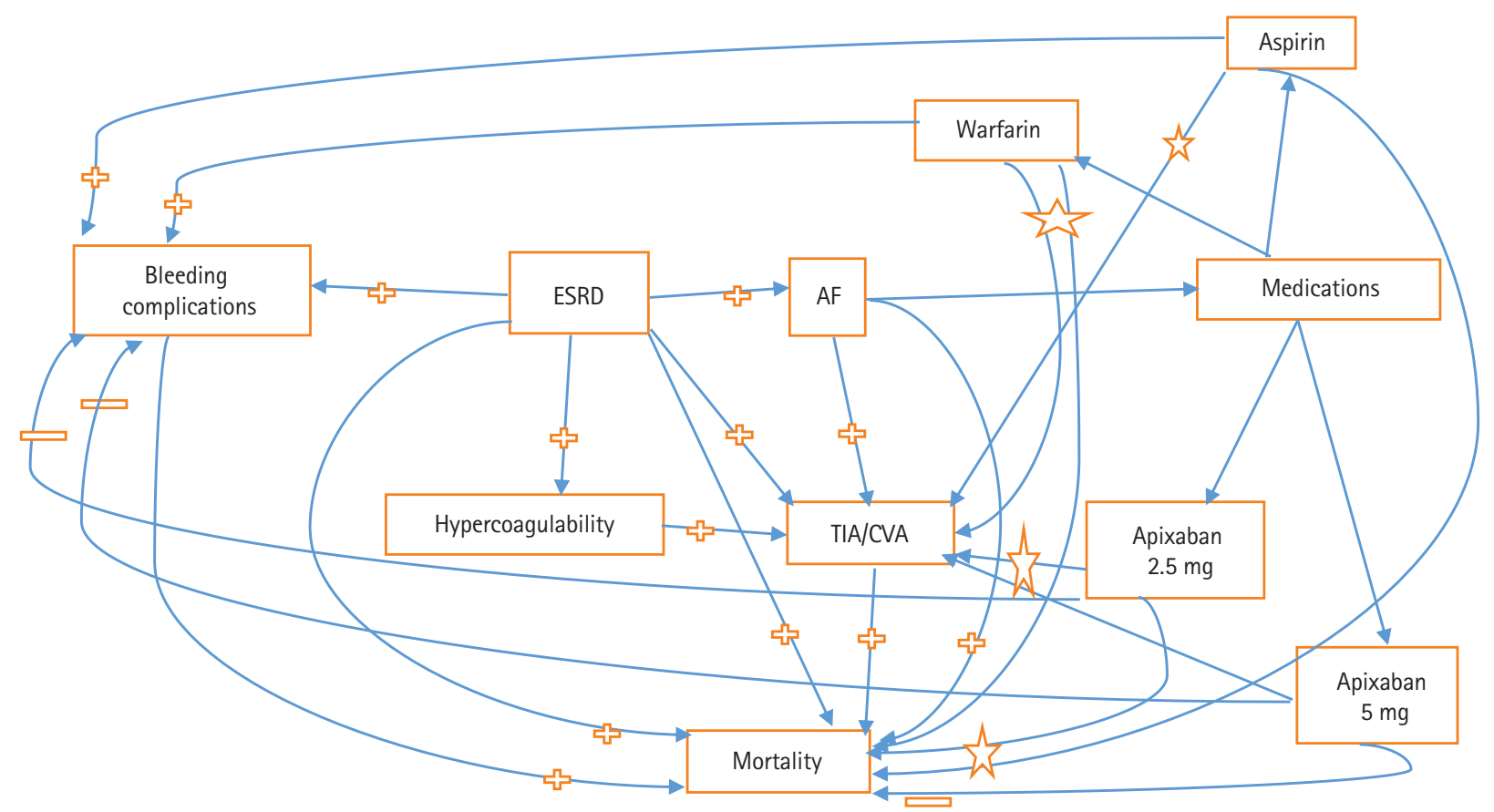

Figure 1. Web of end-stage renal disease (ESRD), atrial fibrillation (AF), and medications. Aspirin: Although data inconclusive, but it is somewhat in favor of lower risk of stroke and mortality but at increased risk of bleeding. Warfarin: Associated with increased risk of bleeding but inconclusive data on stroke risk reduction and mortality. Apixaban: Mortality with apixaban $5 \mathrm{mg}$ lower as compared to apixaban $2.5 \mathrm{mg}$ and warfarin; risk of bleeding lower with apixaban as compared to warfarin, risk of transient ischemic attack (TIA)/cerebrovascular accident (CVA) possibly lower with apixaban 5 mg as compared to apixaban $2.5 \mathrm{mg}$ but not as compared with warfarin. Increased, §; Decreased, $\square$; Inconclusive, 2 . 
ESRD patients (21.1 per 1,000 patient years vs. 4.7 per 1,000 patient years). ${ }^{11} \mathrm{PD}$ patients are found to be at lower risk of hemorrhagic stroke as compared to $\mathrm{HD}$ patients $(\mathrm{HR}, 0.75 ; 95 \% \mathrm{Cl}$, 0.58 to 0.96$)$ and no such significant difference was noted for ischemic stroke. However, regardless of dialysis modality, when compared to the general population, the risk of hemorrhagic stroke among $\mathrm{HD}(\mathrm{HR}, 6.83 ; 95 \% \mathrm{Cl}, 5.89$ to 7.92$)$ and $\mathrm{PD}(\mathrm{HR}$ $6.15 ; 95 \% \mathrm{Cl}, 4.83$ to 7.84$)$ patients is increased far more than the risk of ischemic stroke among $\mathrm{HD}(\mathrm{HR}, 2.88 ; 95 \% \mathrm{Cl}, 2.6$ to 3.19) and $\mathrm{PD}(\mathrm{HR}, 3.21 ; 95 \% \mathrm{Cl}, 2.69$ to 3.83$)$ patients. ${ }^{12}$ Thirty days mortality risk with hemorrhagic stroke as compared to ischemic stroke is also significantly higher (53.4\% vs. $17.9 \%) .{ }^{11}$

Occurrence of AF across the various spectrum of kidney diseases portend poor clinical outcomes. AF in transplant recipients is also associated with graft loss and mortality. But the risk of $\mathrm{CVA} / \mathrm{TIA}$ is significantly lowered with kidney transplantation (24.6 events per 1,000 patient years) as compared to those on dialysis (45.6 events per 1,000 patient years). ${ }^{13}$ Incident AF in patients with CKD is also associated with an increased risk of developing ESRD, stroke, and death. ${ }^{14,15}$ In a retrospective analysis of incident CKD patients $(n=16,451)$ from 2000 to 2013, authors reported 612 patients with AF at baseline (prevalent) and 588 patients who developed AF (incident) during the course. Both incident and prevalent AF group had higher risk of developing ESRD, stroke or systemic thromboembolism and death with highest risk among CKD patients with incident AF (HR, 2.90; 95\% $\mathrm{Cl}, 2.73$ to $3.08 ; P<0.0001$ for ESRD) (HR, 1.82; $95 \% \mathrm{Cl}$, 1.67 to $1.97 ; P<0.0001$ for stroke) $(\mathrm{HR}, 2.49 ; 95 \% \mathrm{Cl}, 2.36$ to 2.62; $P<0.0001$ for all-cause mortality). ${ }^{16}$ Incident ESRD patients with baseline AF were reported to have higher $\mathrm{CV}$ and cerebrovascular disease $(\mathrm{HR}, 1.87 ; 95 \% \mathrm{Cl}, 1.26$ to $2.78 ; P<0.01)$ including death $(\mathrm{HR}, 1.87 ; 95 \% \mathrm{Cl}, 1.17$ to $3.0 ; P<0.01)$ as compared to those without $A F^{17}$ Incident $A F$ in prevalent ESRD patients was also noted to be associated with increased mortality risk. ${ }^{4}$ Therefore, $\mathrm{AF}$ in the presence of kidney disease deserves special attention and management.

\section{Pathophysiology of AF and CVA in ESRD}

Pathophysiology behind increased risk of AF among ESRD is the increased prevalence of traditional risk factors for AF. In addition, ESRD state is also associated with chronic fluid and pressure overload, activation of sympathetic nervous system and renin angiotensin aldosterone system, inflammation, oxidative stress, electrolytes abnormalities, hemodynamic changes, extracellular remodeling, and ventricular hypertrophy which lead to atrial electrophysiological and structural changes and eventually to
AF. ${ }^{18}$ Presence of congestive heart failure (CHF) is increased as $40.4 \%, 28.3 \%$, and $14.4 \%$ in $\mathrm{HD}, \mathrm{PD}$, and transplant patients, respectively. AF in the presence of increased age, hypertension, and $\mathrm{CHF}$ is known to be associated with an increased risk of CVA and TIA. Without any surprise, HD, PD, and transplant patients are all reported to have an increased prevalence of CVA/TIA events as $16.3 \%, 12.4 \%$, and $7.1 \%$, respectively. ${ }^{2}$ Cerebral microbleed (CMB), focal deposits of hemosiderin, is another pathophysiological aspect, which is associated with an increased risk of intracerebral hemorrhage (ICH), ischemic and hemorrhagic stroke, and is quite common among HD patients (54\%). ${ }^{19}$ Mechanism for CMB includes uremia induced alteration in actin cytoskeleton and claudin-5 expression, a tight junction protein in endothelial cells. ${ }^{20}$ Impaired renal function, age, and hypertension were all found to be associated with CMB in patients with ischemic stroke. ${ }^{21}$ In a meta-analysis of studies involving recent ischemic stroke, documented AF and long term anti-coagulation therapy, future odds of $\mathrm{ICH}$ were noted to be associated with the presence of $\mathrm{CMB}$ at baseline (odds ratio [OR], 2.68; 95\% Cl, 1.19 to 6.01 ; $P=0.017$ ) and the number of $\mathrm{CMB}(\mathrm{OR}$ for $\mathrm{ICH}, 5.5 ; 95 \% \mathrm{Cl}$, 2.07 to $14.66 ; P=0.001$ with $\mathrm{CMB} \geq 5$ ). In another review of 504 patients with ischemic stroke and $A F$, presence of $C M B \geq 5$ was associated with all-cause $(H R, 1.99)$ and ischemic stroke mortality $(H R, 3.39)$. Moreover, hemorrhagic stroke mortality $(H R, 5.91)$ was particularly increased with lobar CMB. ${ }^{22}$ Hence, detailed information on CMB can further help risk-stratify ESRD patients. ${ }^{23}$

In view of above mentioned epidemiology, it would seem apparent that ESRD patients with AF and such increased risk of CVA/TIA and mortality be considered for systemic anticoagulation with minimal side effects and aim to reduce the morbidity and mortality related with thromboembolic events. However, it is important for the clinicians to be aware about their hypercoagulable state and concomitant increased risk of bleeding.

\section{Pathophysiology of hypercoagulable state in ESRD}

Risk of deep vein thrombosis is significantly higher among ESRD patients as compared to non-ESRD patients (adjusted HR [aHR], $13.92 ; 95 \% \mathrm{Cl}, 9.25$ to 20.95 ), likely due to their hypercoagulable state. ${ }^{24}$ Patients with kidney disease have an increased level and/ or activity of numerous pro-inflammatory and pro-coagulant factors such as C-reactive protein, cystatin C, interleukin 6 (IL-6), fibrinogen, factor VII, VIII, IX-XII, IL-6, tumor necrosis factor a soluble receptor-1, intracellular adhesion molecule-1, vonWillebrand factor, plasminogen activator inhibitor-1, homocysteine, thromboplastin, and fibrinopeptide $\mathrm{A}$. In addition, there is a decreased level of anticoagulant protein $\mathrm{C}^{24}$ 
Amongst dialysis patients, clot lysis time has been noted to be significantly prolonged, suggesting a hypofibrinolytic state. ${ }^{25}$ As compared to $\mathrm{HD}$, patients on PD may be at higher risk of thrombosis due to increased pro-coagulant factors and macrophage activation, increased presence of thromboplastin and plasminogen activator in the peritoneal cavity from exposure to the dialysate. ${ }^{26}$ Kidney transplant recipients also exhibit pro-thrombotic and inflammatory state. These patients have increased level of fibrinogen, d-dimer, IL-6, thrombin generation, pro-thrombin activation fragment, post-transplant erythrocytosis leading to hypercoagulable state. $^{27}$

\section{Pathophysiology of increased risk of bleeding in ESRD}

On one hand ESRD patients are hypercoagulable, while on the other, they are at an increased risk of bleeding due to abnormal primary hemostasis involving vasoconstriction, platelet adhesion, and aggregation rather than impairment of secondary hemostasis mechanisms (coagulation pathways) or fibrinolysis. ${ }^{28}$ There is a great degree of platelet dysfunction among ESRD owing to decreased platelet activity, recruitment, adhesion, and aggregation along with impaired interaction among platelets and endothelium. ${ }^{29,30}$ In a study evaluating hemostasis among ESRD patients, authors found decreased thrombin generating capacity and clopidogrel like platelet dysfunction. ${ }^{25,31}$ Furthermore, patients on $\mathrm{HD}$ are frequently given intravenous heparin during the treatment which can increase the risk of bleeding. Mechanisms behind platelet dysfunction and impaired interaction between platelet and endothelium in ESRD patients are listed in Table 1.

\section{Pros and cons of AF and systemic anticoagulation in ESRD}

ESRD patients with $A F$, without treatment with systemic anti-

Table 1. Mechanisms behind impaired platelet function and endothelium interaction in end-stage renal disease

Mechanisms of platelet dysfunction ${ }^{30}$

Impairment of arachidonic acid and prostaglandin metabolism Disturbance of platelet $\alpha$-granules

Impairment of thromboxane $A_{2}$ synthesis and/or release

Competitive binding of circulating fibrinogen fragments to glycoprotein Ill/IIla receptor on platelets

Uremic toxins, oxidative stress and inflammatory state

Mechanisms of impaired interaction between platelet and endothelium ${ }^{30}$

Decrease in platelet GPIb receptor

Inadequate binding of vWF and fibrinogen to activated platelets Increased level of prostacyclin and nitric oxide

GP1b, glycoprotein 1b; vWF, von-Willebrand factor. coagulation or antiplatelet agents, have an increased risk of ischemic stroke (incidence of 6.9 per 100 patient years)..$^{32}$ In a study of 5,629 incident ESRD patients with AF, rate of ischemic and hemorrhagic stroke were 22.8 and 5.0 per 1,000 patient years, respectively. However, chronic AF was noted to be associated with increased risk of ischemic stroke only (HR, 1.26; 95\% $\mathrm{Cl}, 1.06$ to $1.49 ; P=0.0005)$, not hemorrhagic. ${ }^{33}$ Chang et al., ${ }^{8}$ found comparable incidence of ischemic stroke in $\mathrm{HD}$ and $\mathrm{PD}$ patients ( $\mathrm{HR}, 1.07 ; 95 \% \mathrm{Cl}, 0.80$ to 1.44$)$ but much lower risk of hemorrhagic stroke in PD patients as compared to HD patients ( $\mathrm{HR}, 0.34 ; 95 \% \mathrm{Cl}, 0.13$ to 0.90$)$. Kidney transplant patients are also at increased risk of AF and CVA/TIA which occurred in over $7 \%$ of recipients and within 3 years of transplantation. Incidence of AF is reported to be highest in peri-transplant period..$^{13}$

Occurrence of stroke among ESRD patients leads to poor outcomes. In an analysis of matched cohort of patients hospitalized with acute ischemic stroke, risk of in-hospital mortality (7.6\% vs. $5.2 \%, P<0.001)$, sepsis ( $4 \%$ vs. $2.5 \%, P<0.001)$, median length of stay ( 6 days vs. 5 days, $P<0.001$ ), and median cost of care $(11,046 \$$ vs. $10,357 \$, P<0.001)$ were all increased among ESRD patients as compared to the non-dialysis patients. Moreover, 52.6\% of ESRD patients admitted with stroke were not able to be discharged home. Utilization of gastrostomy (5.6\%) and mechanical ventilation (2.8\%) was also increased owing to stroke related complications. ${ }^{34}$

ESRD patients especially on HD are at an increased risk of bleeding especially upper gastrointestinal (GI) bleeding secondary to angiodysplasia and erosive esophagitis..$^{35}$ It can also be due to other causes such as, arteriovenous access related, oral/ nasal or genitourinary bleeding. ${ }^{35}$ Risks of in-hospital mortality, need for blood transfusion, re-bleeding, hospitalization, and length of stay are all increased among ESRD patients with GI bleeding. ${ }^{36}$ Risk of both non-traumatic and traumatic subdural hemorrhage is increased among ESRD patients which is much more pronounced with $\mathrm{HD}$ modality as compared to PD (aHR, $1.62 ; 95 \% \mathrm{Cl}, 1.17$ to 2.33). History of AF and use of medications such as anti-platelets and warfarin were associated with an increased risk of subdural hemorrhage in this cohort. Subdural hemorrhage is also associated with an increased risk of mortality at 30 days. ${ }^{37}$ Risk of bleeding is significantly increased in patients with kidney transplantation too, as compared to general population (relative risk, 8.2; 95\% Cl, 6.9 to 9.7 ). ${ }^{38}$ In a study of 255 ESRD patients, risk of major bleed was increased greatest with use of aspirin and warfarin (6.3\% per person-year of exposure; $95 \% \mathrm{Cl}, 2.1$ to $14.8 ; P=0.006)$. Such risk was $3.1 \%$ per person of year exposure to warfarin alone $(95 \% \mathrm{Cl}, 1$ to 7.3 ; $P=0.07$ ) and $4.4 \%$ per person of year exposure to aspirin alone $(95 \% \mathrm{Cl}, 2.3$ to $7.7 ; P=0.002){ }^{39}$ However, there was no in- 
creased risk of intracranial hemorrhage or Gl bleeding or death with use of warfarin. These findings raise concerns regarding increased risk of stroke without anticoagulants but increased risk of bleeding when these medications are given and therefore, confusion about therapeutic choices prevails.

\section{Predicting stroke versus bleeding}

We need tools to stratify ESRD patients regarding their risk of CVA/TIA and bleeding to better identify patients who could be offered anticoagulants safely. At present, $\mathrm{CHA}_{2} \mathrm{DS}_{2}$-VASc $\left(\mathrm{CHF}_{1}\right.$ hypertension, age $\geq 75$ years, diabetes mellitus, stroke/TIA, vascular disease, age 65 to 74 years, and female sex) is the recommended model for stroke risk stratification in patients with $\mathrm{AF}^{40}$ Even though, presence of CKD and ESRD is associated with an increased risk of $\mathrm{TIA} /$ stroke in patients with $\mathrm{AF}$, it is not included in this risk scoring. Observational studies have evaluated the performance of these risk scoring methods. In an ESRD cohort of 10,999 patients, both $\mathrm{CHADS}_{2}$ and $\mathrm{CHA}_{2} \mathrm{DS}_{2}$-VASc scores were significant predictors of stroke, but $\mathrm{CHA}_{2} \mathrm{DS}_{2}$-VASc score performed better than the $\mathrm{CHADS}_{2}$ score. ${ }^{32}$ Anticoagulant and risk factors in AF (ATRIA), another scoring system proposed which also gave points to proteinuria and estimated glomerular filtration rate $<45 \mathrm{~mL} / \mathrm{min} / 1.73 \mathrm{~m}^{2}$ or ESRD, has performed better in term of identifying low stroke risk patients. ${ }^{40}$ Lately, The Global Anticoagulant Registry in the FIELD-Atrial Fibrillation (GARFIELD-AF) score which also included CKD stage 3 and 4 has been shown to be superior to $\mathrm{CHA}_{2} \mathrm{DS}_{2}$-VASc in predicting risk of stroke and mortality. ${ }^{41}$

There are various risk scoring systems developed to assess bleeding risk as well. While comparing Hypertension, Abnormal liver/kidney function, Stroke, Bleeding, Labile INR, Elderly, Drugs or alcohol (HAS-BLED), Outcomes Registry for Better Informed Treatment (ORBIT), Anticoagulation and Risk Factors in Atrial Fibrillation (ATRIA), and Hepatic or Renal Disease, Ethanol Abuse, Malignancy, Older Age, Reduced Platelet Count or Function, Re-Bleeding, Hypertension, Anemia, Genetic Factors, Excessive Fall Risk and Stroke (HEMORR ${ }_{2}$ HAGES) bleeding risk scores, Proietti et al. ${ }_{1}^{42}$ found best discrimination and calibration with ORBIT score. GARFIELD-AF score which performs comparable to HAS-BLED risk score, also provides comparison of different anticoagulant choices. But, most of these scoring systems do not take ESRD status into consideration. Hence, ESRD patients are greatly in need of a separate risk stratification model taking into account their predisposing factors for stroke/bleeding, co-morbidities, CMBs, modality and duration of dialysis so that decision making can be guided regarding treatment options to reduce the risk of TIA/stroke and bleeding as well. At present, antiplatelet agents, warfarin and DOAC are the medications available for use in patients with AF for CVA/TIA prevention, which will be discussed below in the context of ESRD patients.

\section{Use of antiplatelet agents in ESRD for CVA/TIA prevention}

A recent study focused on effectiveness and safety of antiplatelet agent in ESRD patients with ischemic stroke. This study analyzed 1,936 ESRD patients with first ischemic stroke, primary outcome being death and readmission for stroke and secondary outcome as bleeding, stroke, acute myocardial infarction, and death. Authors found decreased risk for the primary outcome with aspirin treatment $(H R, 0.671 ; P<0.001)$. Specifically, risk for readmission with stroke (HR, 0.72; $P=0.002)$ was significantly reduced with aspirin without an increased risk of bleeding $(H R, 0.885 ; P=0.291) .{ }^{43}$ However, in another study of $901 \mathrm{AF}$ patients requiring renal replacement therapy (RRT), use of aspirin or aspirin with warfarin was not associated with the decreased risk of stroke or thromboembolism. ${ }^{5}$ Choice of RRT such as HD, PD, or transplantation did not affect the outcome in these patients either. ${ }^{5}$ In a retrospective Danish study, risk for the composite of stroke and bleeding with use of aspirin in low stroke risk $\left(\mathrm{CHA}_{2} \mathrm{DS}_{2}\right.$-VASc score $\left.=0\right)$ patients on $\mathrm{HD}(\mathrm{HR}, 1.17 ; 95 \% \mathrm{Cl}, 0.61$ to 3.60$)$ was similar to those on $\mathrm{PD}(\mathrm{HR}, 1.83 ; 95 \% \mathrm{Cl}, 0.51$ to 6.49$)$ with $P$-value of 0.749 for $P D$ and $H D$ interaction. However, in patients at high risk for CVA ( $\mathrm{CHA}_{2} \mathrm{DS}_{2}$-VASc score $\geq 2$ ), risk for such outcomes were lower in PD patients $(\mathrm{HR}, 0.74 ; 95 \% \mathrm{Cl}, 0.42$ to 1.31$)$ as compared to $\mathrm{HD}$ patients $(\mathrm{HR}, 1.07 ; 95 \% \mathrm{Cl}, 0.80$ to 1.42$)$ with significant $P$-value $(0.041)$ for $\mathrm{PD}$ and $\mathrm{HD}$ interaction. ${ }^{44}$

On the contrary, antiplatelet medication use in ESRD was associated with an increased risk of bleeding especially among those with diabetes mellitus. ${ }^{45}$ Olesen et al. ${ }_{1}^{5}$ also reported increased risk of bleeding in ESRD with aspirin use ( $H R, 1.63 ; 95 \%$ $\mathrm{Cl}, 1.18$ to 2.26; $P=0.003$ ). Risk of bleeding was slightly more pronounced with combination of warfarin and aspirin (HR, 1.71; $95 \% \mathrm{Cl}, 0.98$ to 2.99; $P=0.06$ ). Bleeding risk (ICH) was more pronounced with aspirin use among patients with severe hypertension (pre-dialysis systolic blood pressure $>160 \mathrm{~mm} \mathrm{Hg}$ ). ${ }^{46}$ Due to conflicting data regarding risks and benefits of antiplatelet medication use among ESRD patients with AF, there is no consensus or guideline regarding their routine use. Results from a randomized controlled trial to assess aspirin use in ESRD patients to reduce the risk of thrombotic events are awaiting. ${ }^{47}$ 


\section{Use of warfarin in ESRD for CVA/TIA prevention}

Role of warfarin, a vitamin $\mathrm{K}$ antagonist, remains unclear and uncertain in ESRD with AF for CVA/TIA prevention. In a retrospective analysis of $56,587 \mathrm{HD}$ patients with $A F$, warfarin use was associated with lower risk of ischemic stroke and death without an increased risk of $\mathrm{Gl}$ bleeding..$^{10}$ In a meta-analysis of all observational studies, authors did not find a statistically significant reduction in stroke risk (14 studies; 20,398 participants; aHR, $0.77 ; 95 \% \mathrm{Cl}, 0.55$ to 1.07$).{ }^{48}$ Surprisingly, there was no statistically significant increased risk of intracranial hemorrhage (four studies; 15,726 participants; aHR, 1.93; 95\% Cl, 0.93 to 4.00) or Gl bleeding (three studies; 14,693 participants; aHR, $1.19 ; 95 \% \mathrm{Cl}, 0.8$ to 1.76 ) or death (seven studies; 16,172 participants; aHR, $0.89 ; 95 \% \mathrm{Cl}, 0.72$ to 1.11 ) with use of warfarin either. On the contrary, Abuhasira et al. ${ }_{1}{ }^{4}$ had reported a higher risk of CVA with use of warfarin in ESRD patients as compared to no warfarin ( $24.2 \%$ vs. $12.9 \%, P=0.026)$ and statistically non-significant increased risk of major bleeding $(16.7 \%$ vs. $9.2 \%, P=0.09$ ). In particular, risks of hemorrhagic stroke (aHR, $1.22 ; 95 \% \mathrm{Cl}, 1.03$ to 1.46 ) and calciphylaxis (aHR, 1.49; 95\% $\mathrm{Cl}, 1.05$ to 1.91 ) were increased with warfarin use. ${ }^{10}$ In another meta-analysis of 56,146 patients with ESRD and AF, warfarin use was again not associated with reduction in stroke risk $(\mathrm{HR}, 0.92 ; 95 \% \mathrm{Cl}, 0.74$ to 1.16$)$. Instead, it was associated with increased risk of bleeding ( $\mathrm{HR}, 1.21 ; 95 \% \mathrm{Cl}, 1.01$ to 1.44$).{ }^{49}$ Similar results were reported in meta-analysis of $17,380 \mathrm{HD}$ patients whereby risk reduction of ischemic stroke (HR, 0.74; 95\% $\mathrm{Cl}, 0.51$ to 1.06$)$ and mortality $(\mathrm{HR}, 1.00 ; 95 \% \mathrm{Cl}, 0.92$ to 1.09$)$ was not significant with warfarin use. Rather, a $21 \%$ increase in total bleeding risk ( $\mathrm{HR}, 1.21 ; 95 \% \mathrm{Cl}, 1.03$ to 1.43$)$ was noted..$^{50}$ There are no specific guidelines for or against use of warfarin in kidney transplant recipients. In a transplant cohort, warfarin use did not have impact on risk of ischemic or hemorrhagic stroke or Gl bleeding. ${ }^{51}$ There is a paucity of data regarding warfarin use in PD patients and AF. In a subgroup analysis, PD patients with a $\mathrm{CHA}_{2} \mathrm{DS}_{2}-\mathrm{VASc}$ score $=0$ were at quite high risk of stroke/ bleeding ( $\mathrm{HR}, 4.67 ; 95 \% \mathrm{Cl}, 1.56$ to 14.03$)$ and all cause death $(\mathrm{HR}, 2.61 ; 95 \% \mathrm{Cl}, 1.29$ to 5.28$)$ with the use of warfarin. This was noted not to be significant for stroke/bleeding $(\mathrm{HR}, 1.19$; $95 \% \mathrm{Cl}, 0.63$ to 2.24$)$ or all cause death $(\mathrm{HR}, 0.78 ; 95 \% \mathrm{Cl}, 0.56$ to 1.11) for those with $\mathrm{CHA}_{2} \mathrm{DS}_{2}$-VASc score $\geq 2 .{ }^{44}$ These findings are worrisome regarding safety and efficacy of warfarin in dialysis patients with $A F$, who are already at an increased risk of bleeding and hemorrhagic strokes.

\section{Use of DOACs in ESRD for CVA/TIA prevention}

DOACs are the preferred choice of anticoagulants in the general population owing to reduced risk of bleeding, and non-inferior and/or superior risk reduction in stroke, as compared to warfarin. In addition, there is no need for therapeutic monitoring or dietary restrictions with the use of DOACs which is a desired feature for any medication use in ESRD. ${ }^{52}$ Unfortunately, randomized trials involving these agents did not include ESRD patients. Hence, data regarding safety and efficacy of these agents is solely based upon observational data. Direct thrombin inhibitors such as dabigatran are not approved for use in patients with ESRD. ${ }^{52}$ Similarly, other novel oral anticoagulants, which inhibit factor $\mathrm{X}$, such as edoxaban and rivaroxaban are not approved for use in ESRD. In a single dose study of rivaroxaban $15 \mathrm{mg}$ given 3 hours after or 2 hours before a 4 hours HD session, systemic exposure was $56 \%$ and $47 \%$ higher, respectively, as compared to patients with normal kidney function. ${ }^{53}$ While rivaroxaban is not approved for use in ESRD with AF for stroke risk reduction at present, it may change in future with more study results and data analysis.

Recently in 2014, apixaban which is also a factor Xa inhibitor, was approved for use in ESRD, even though trials involving apixaban did not include ESRD patients. ${ }^{54,55}$ Dosage recommendations from manufacturers are solely based upon one study whereby single dose exposure of apixaban $5 \mathrm{mg}$ to ESRD patients resulted in 36\% higher area under curve (AUC) and no increase in maximum concentration (Cmax) of drug as compared to healthy subjects. HD session led to $13 \%$ and $14 \%$ reduction of Cmax and AUC for apixaban, respectively. ${ }^{56}$ However, in a subsequent pharmacological study of apixaban in HD patients, dosage of $5 \mathrm{mg}$ twice daily (standard dose) resulted in supra-therapeutic levels and were recommended to be avoided. However, drug exposure from dosage of $2.5 \mathrm{mg}$ twice daily (reduced dose) in $\mathrm{HD}$ patients was comparable to dosage of $5 \mathrm{mg}$ twice daily in patients with preserved renal function. ${ }^{55}$ Hence, there is great degree of confusion about its dosage for ESRD patients which is further compounded by conflicting observational data.

Among ESRD patients treated with dosage of apixaban $2.5 \mathrm{mg}$ twice daily $(n=1,317)$ and apixaban $5 \mathrm{mg}$ twice daily $(n=1,034)$, authors did not found any increased risk of bleeding with standard dose as compared with reduced dose. However, the risks of stroke $(\mathrm{HR}, 0.64 ; 95 \% \mathrm{Cl}, 0.42$ to $0.97 ; P=0.04)$ and death (HR, $0.63 ; 95 \% \mathrm{Cl}, 0.46$ to $0.85 ; P=0.003$ ) were lower with standard dose. ${ }^{57}$ In a meta-analysis involving five studies and 43,850 advanced CKD and ESRD patients, apixaban was associated with lower risk of bleeding but similar risk of thromboembolic event 
Table 2. Pharmacologic agents and outcomes in ESRD patients with AF

\begin{tabular}{|c|c|c|c|c|c|c|}
\hline Study year & Author & Study design & Study participants & Outcome & Stroke/thromboembolism & Bleeding \\
\hline \multicolumn{7}{|l|}{$\begin{array}{l}\text { Antiplatelet } \\
\text { agent: aspirin }\end{array}$} \\
\hline 1997-2008 & Olesen et al..$^{5}$ & $\begin{array}{l}\text { Retrospective } \\
\text { observation- } \\
\text { al (Cox-re- } \\
\text { gression } \\
\text { analysis) }\end{array}$ & $\begin{array}{l}\text { All patients discharged from } \\
\text { the hospital with a diagno- } \\
\text { sis of non-valvular AF } \\
(n=901)\end{array}$ & $\begin{array}{l}\text { Primary: hospitalization or } \\
\text { death from stroke or systemic } \\
\text { thromboembolism, bleeding } \\
\text { Secondary: risk of stroke or } \\
\text { systemic thromboembolism } \\
\text { (excluding TIA) }\end{array}$ & $\begin{array}{l}\mathrm{HR}, 0.88 ; 95 \% \mathrm{Cl}, 0.59- \\
\quad 1.32 ; P=0.54\end{array}$ & $\begin{array}{l}\mathrm{HR}, 1.63 ; 95 \% \mathrm{Cl}, 1.18- \\
\quad 2.26 ; P=0.003\end{array}$ \\
\hline 1997-2011 & Bonde et al. ${ }^{44}$ & $\begin{array}{l}\text { Retrospective } \\
\text { observation- } \\
\text { al }\end{array}$ & $\begin{array}{l}\text { All patients discharged from } \\
\text { hospital with diagnosis of } \\
\text { non-valvular AF and RRT } \\
(n=1,728)\end{array}$ & $\begin{array}{l}\text { Hospitalization/death from } \\
\text { stroke/thromboembolism, a } \\
\text { composite of fatal stroke/ } \\
\text { fatal bleeding }\end{array}$ & $\begin{array}{l}\mathrm{HR}, 1.82 ; 95 \% \mathrm{Cl}, 1.55- \\
\quad 2.14\end{array}$ & $\begin{array}{l}\text { HR for all stroke or all bleed- } \\
\text { ing 1.06; } 95 \% \mathrm{Cl}, 0.83- \\
1.36^{*}\end{array}$ \\
\hline 1998-2006 & Chen et al. ${ }^{43}$ & $\begin{array}{l}\text { Retrospective } \\
\text { observation- } \\
\text { al }\end{array}$ & $\begin{array}{l}\text { ESRD patients on dialysis af- } \\
\text { ter first-time ischemic } \\
\text { stroke }(n=1,936)\end{array}$ & $\begin{array}{l}\text { Primary: death and readmission } \\
\text { to hospital for stroke } \\
\text { Secondary: death, stroke or } \\
\text { bleeding }\end{array}$ & $\begin{array}{l}\text { HR for primary outcomes } \\
\text { in patients treated with } \\
\text { aspirin, } 0.67 ; P<0.001 \\
\text { HR for readmission for } \\
\text { stroke, } 0.72 ; P=0.002\end{array}$ & $\mathrm{HR}, 0.89 ; P=0.291$ \\
\hline \multicolumn{7}{|l|}{$\begin{array}{l}\text { Vitamin K an- } \\
\text { tagonist: } \\
\text { warfarin }\end{array}$} \\
\hline 1997-2008 & Olesen et al. ${ }^{5}$ & $\begin{array}{l}\text { Retrospective } \\
\text { observation- } \\
\text { al (Cox-re- } \\
\text { gression } \\
\text { analysis) }\end{array}$ & $\begin{array}{l}\text { All patients discharged from } \\
\text { the hospital with a diagno- } \\
\text { sis of non-valvular AF } \\
(n=901)\end{array}$ & $\begin{array}{l}\text { Primary- hospitalization or } \\
\text { death from stroke or systemic } \\
\text { thromboembolism, bleeding } \\
\text { Secondary: risk of stroke or } \\
\text { systemic thromboembolism } \\
\text { (excluding TIA) }\end{array}$ & $\begin{array}{l}\text { With warfarin use: } \mathrm{HR}, \\
0.44 ; 95 \% \mathrm{Cl}, 0.26-0.74 ; \\
P=0.002\end{array}$ & $\begin{array}{l}\mathrm{HR}, 1.27 ; 95 \% \mathrm{Cl}, 0.911- \\
\quad 1.77 ; P=0.15\end{array}$ \\
\hline 1997-2011 & Bonde et al. ${ }^{44}$ & $\begin{array}{l}\text { Retrospective } \\
\text { observation- } \\
\text { al }\end{array}$ & $\begin{array}{l}\text { All patients discharged from } \\
\text { hospital with diagnosis of } \\
\text { non-valvular AF and RRT } \\
(n=1,728)\end{array}$ & $\begin{array}{l}\text { Hospitalization/death from } \\
\text { stroke/thromboembolism, a } \\
\text { composite of fatal stroke/ } \\
\text { fatal bleeding }\end{array}$ & $\begin{array}{l}\text { Rate per } 100 \text { person-years } \\
\text { with use of warfarin, 4.8; } \\
95 \% \mathrm{Cl}, 3.2-6.4 \text {; as } \\
\text { compared to no warfa- } \\
\text { rin, } 7.3 ; 95 \% \mathrm{Cl}, 6.2-8.5\end{array}$ & $\begin{array}{l}\text { HR for all stroke/bleeding, } \\
\quad 1.06 ; 95 \% \mathrm{Cl}, 0.83-1.36\end{array}$ \\
\hline 1998-2007 & Shah et al. ${ }^{61}$ & $\begin{array}{l}\text { Retrospective } \\
\text { cohort }\end{array}$ & $\begin{array}{l}\text { Patients aged } \geq 65 \text { years ad- } \\
\text { mitted to a hospital with a } \\
\text { diagnosis of AF (dialysis } \\
\text { patients } n=1,626 \text { ) }\end{array}$ & $\begin{array}{l}\text { First hospital admission or } \\
\text { emergency department visit } \\
\text { for stroke or bleeding }\end{array}$ & $\begin{array}{l}\text { Stroke: } \mathrm{HR}, 1.14 ; 95 \% \mathrm{Cl} \\
0.78-1.67\end{array}$ & $\begin{array}{l}\text { Bleeding: } \mathrm{HR}, 1.44 ; 95 \% \mathrm{Cl} \text {, } \\
\text { 1.13-1.85 }\end{array}$ \\
\hline 2002-2015 & $\begin{array}{l}\text { Abuhasira et } \\
\text { al. }^{4}\end{array}$ & $\begin{array}{l}\text { Retrospective } \\
\text { cohort }\end{array}$ & $\begin{array}{l}\text { All patients who initiated di- } \\
\text { alysis during the study pe- } \\
\text { riod and developed AF } \\
(n=304)\end{array}$ & CVA and major bleeding event & $\begin{array}{l}\text { Risk of CVA with use of } \\
\text { warfarin as compared to } \\
\text { no warfarin }(24.2 \% \text { vs. } \\
12.9 \%, P=0.026)\end{array}$ & $\begin{array}{l}\text { Risk with use of warfarin as } \\
\text { compared to no } \\
\text { warfarin ( } 16.7 \% \text { vs. } 9.2 \% \text {, } \\
P=0.09)\end{array}$ \\
\hline $2006-2013$ & $\begin{array}{l}\text { Waddy et } \\
{\text { al. } .^{10}}^{\text {a }}\end{array}$ & $\begin{array}{l}\text { Retrospective } \\
\text { observation- } \\
\text { al cohort }\end{array}$ & $\begin{array}{l}\text { ESRD patients who initiated } \\
\text { HD and subsequently } \\
\text { diagnosed with AF } \\
(n=56,587)\end{array}$ & $\begin{array}{l}\text { Primary outcome: all-cause } \\
\text { stroke } \\
\text { Secondary outcomes: death, } \\
\text { ischemic stroke, hemorrhagic } \\
\text { stroke, GI bleeding }\end{array}$ & $\begin{array}{l}\text { Ischemic stroke: aHR, 0.79; } \\
95 \% \mathrm{Cl}, 0.66-0.95\end{array}$ & $\begin{array}{c}\text { GI bleeding: aHR, 1.12; } 95 \% \\
\text { Cl, 0.94-1.36 } \\
\text { Hemorrhagic stroke: aHR, } \\
1.22 ; 95 \% \mathrm{Cl}, 1.03-1.46\end{array}$ \\
\hline $2006-2015$ & Kai et al..$^{62}$ & $\begin{array}{l}\text { Propensity } \\
\text { score- } \\
\text { matched } \\
\text { cohort }\end{array}$ & $\begin{array}{l}\text { ESRD patients with AF } \\
\quad(n=888)\end{array}$ & Stroke, bleeding, and death & $\begin{array}{l}\text { Ischemic stroke: } \mathrm{HR}, 0.68 \\
95 \% \mathrm{Cl}, 0.52-0.91\end{array}$ & $\begin{array}{l}\text { GI bleeding: } \mathrm{HR}, 0.97 ; 95 \% \\
\mathrm{Cl}, 0.77-1.2 \\
\text { Hemorrhagic stroke: HR, 1.2; } \\
95 \% \mathrm{Cl}, 0.6-2.2\end{array}$ \\
\hline $2007-2011$ & Shen et al. ${ }^{63}$ & $\begin{array}{l}\text { Retrospective } \\
\text { observation- } \\
\text { al cohort }\end{array}$ & $\begin{array}{l}\text { ESRD patients on HD with } \\
\text { new diagnosis of AF and no } \\
\text { prior use of warfarin } \\
(n=12,284)\end{array}$ & $\begin{array}{l}\text { Death, ischemic stroke, hemor- } \\
\text { rhagic stroke, and severe } \mathrm{Gl} \\
\text { bleeding }\end{array}$ & $\begin{array}{l}\text { Ischemic stroke: } \mathrm{HR}, 0.68 \\
95 \% \mathrm{Cl}, 0.47-0.99\end{array}$ & $\begin{array}{l}\text { GI bleeding: } \mathrm{HR}, 1.00 ; 95 \% \\
\mathrm{Cl}, 0.69-1.44 \\
\text { Hemorrhagic stroke: } \mathrm{HR}_{1} \\
0.82 ; 95 \% \mathrm{Cl}, 0.37-1.81\end{array}$ \\
\hline
\end{tabular}


Table 2. Continued

\begin{tabular}{|c|c|c|c|c|c|c|}
\hline Study year & Author & Study design & Study participants & Outcome & Stroke/thromboembolism & Bleeding \\
\hline $2009-2013$ & Yoon et al..$^{64}$ & $\begin{array}{l}\text { Propensity } \\
\text { matched } \\
\text { cohort }\end{array}$ & $\begin{array}{l}\text { Patients with ESRD and AF } \\
(n=5,548)\end{array}$ & $\begin{array}{l}\text { Ischemic stroke, hemorrhagic } \\
\text { stroke, and GI bleeding }\end{array}$ & $\begin{array}{l}\text { Ischemic stroke: } \mathrm{HR}, 0.95 \\
95 \% \mathrm{Cl}, 0.78-1.15 \\
P=0.569\end{array}$ & $\begin{array}{l}\text { GI bleeding with the warfa- } \\
\text { rin use }(7.5 \%) \text { and no } \\
\text { warfarin use }(6.6 \%) \text {, } \\
P=0.208 \\
\text { Hemorrhagic stroke: HR, } \\
1.56,95 \% \mathrm{Cl}, 1.10-2.22 ; \\
P=0.013\end{array}$ \\
\hline \multicolumn{7}{|l|}{$\begin{array}{l}\text { Direct oral an- } \\
\text { ticoagulant: } \\
\text { apixaban }\end{array}$} \\
\hline 2010-2015 & $\begin{array}{l}\text { Siontis et } \\
\text { al. }^{57}\end{array}$ & $\begin{array}{l}\text { Retrospective } \\
\text { cohort }\end{array}$ & $\begin{array}{l}\text { Patients with AF and ESRD } \\
\text { undergoing dialysis who } \\
\text { initiated treatment with an } \\
\text { oral anticoagulant } \\
(n=25,523)\end{array}$ & $\begin{array}{l}\text { Stroke or systemic embolism, } \\
\text { major bleeding, Gl bleeding, } \\
\text { intracranial bleeding, and } \\
\text { death }\end{array}$ & $\begin{array}{c}\text { Stroke/systemic embolism } \\
\text { for apixaban vs. warfa- } \\
\text { rin: } \mathrm{HR}, 0.88 ; 95 \% \mathrm{Cl} \text {, } \\
0.69-1.12 ; P=0.29\end{array}$ & $\begin{array}{l}\text { Gl bleeding for apixaban vs. } \\
\text { warfarin: } \mathrm{HR}, 0.86 ; 95 \% \\
\mathrm{Cl}, 0.72-1.02 ; P=0.09 \\
\text { Intracranial bleed for apixa- } \\
\text { ban vs. warfarin: } \mathrm{HR}, 0.79 ; \\
95 \% \mathrm{Cl} 0.49-1.26 ; P=0.32\end{array}$ \\
\hline 2017 & $\begin{array}{l}\text { Chokesu- } \\
\text { watt- } \\
\text { anaskul et } \\
\text { al. }^{58}\end{array}$ & Meta-analysis & $\begin{array}{l}\text { Studies that reported bleed- } \\
\text { ing complications or } \\
\text { thromboembolic events in } \\
\text { the use of apixaban in pa- } \\
\text { tients with CKD stage } 4-5 \\
\text { or ESRD on dialysis (5 } \\
\text { studies, 43,850 patients) }\end{array}$ & $\begin{array}{l}\text { Thromboembolic event, major } \\
\text { bleeding }\end{array}$ & $\begin{array}{l}\text { Pooled OR, 0.56; } 95 \% \mathrm{Cl}_{\text {, }} \\
\quad 0.23-1.39\end{array}$ & $\begin{array}{l}\text { Pooled } \mathrm{OR}, 0.42 ; 95 \% \mathrm{Cl} \text {, } \\
\quad 0.28-0.61\end{array}$ \\
\hline 2019 & Kuno et al. ${ }^{59}$ & Meta-analysis & $\begin{array}{l}\text { Studies that investigated the } \\
\text { efficacy and safety of dif- } \\
\text { ferent OAC strategies in } \\
\text { patients with AF on long- } \\
\text { term dialysis }\end{array}$ & $\begin{array}{l}\text { Ischemic stroke/systemic } \\
\text { thromboembolism, major } \\
\text { bleeding, and all-cause mor- } \\
\text { tality }\end{array}$ & $\begin{array}{l}\text { As compared to no-anti- } \\
\text { coagulation, } \\
\text { Apixaban } 2.5 \mathrm{mg}: \mathrm{HR}, \\
\text { 1.00; } 95 \% \mathrm{Cl}, 0.52-1.93 \\
\text { Apixaban } 5 \mathrm{mg}: \mathrm{HR}, 0.59 ; \\
95 \% \mathrm{Cl}, 0.30-1.17\end{array}$ & $\begin{array}{l}\text { Risk of bleeding with } \\
\text { warfarin as compared to } \\
\text { Apixaban } 2.5 \mathrm{mg} \text { : HR, 1.40; } \\
95 \% \mathrm{Cl}, 1.07-1.82 \\
\text { Apixaban } 5 \mathrm{mg} \text { : HR 1.41; } \\
\text { 95\% Cl, 1.07-1.88 }\end{array}$ \\
\hline 2020 & $\begin{array}{l}\text { Mavrakanas } \\
\text { et al. } .^{65}\end{array}$ & $\begin{array}{c}\text { Propensity } \\
\text { cohort }\end{array}$ & $\begin{array}{l}\text { Patients on maintenance di- } \\
\text { alysis with incident, non- } \\
\text { valvular AF treated with } \\
\text { apixaban }(n=521)\end{array}$ & $\begin{array}{l}\text { Primary outcome: hospitaliza- } \\
\text { tion for new CVA, TIA, or } \\
\text { systemic thromboembolism } \\
\text { Secondary outcome: fatal or } \\
\text { intracranial bleeding }\end{array}$ & $\begin{array}{l}\text { Ischemic stroke for apixa- } \\
\text { ban as compared to no } \\
\text { treatment: } H R, 0.85 \\
95 \% \mathrm{Cl}, 0.36-1.98 \\
P=0.71\end{array}$ & $\begin{array}{l}\text { Major bleeding for apixaban } \\
\text { as compared to no treat- } \\
\text { ment: } \mathrm{HR}, 2.76 ; 95 \% \mathrm{Cl} \text {, } \\
\text { 1.38-5.52; } P=0.004 \\
\text { Hemorrhagic stroke for } \\
\text { apixaban as compared to } \\
\text { no treatment: } \mathrm{HR}, 1.89 ; \\
95 \% \mathrm{Cl}, 0.65-5.49 ; P=0.24\end{array}$ \\
\hline
\end{tabular}

ESRD, end-stage renal disease; $A F$, atrial fibrillation; TIA, transient ischemic attack; $H R$, hazard ratio; $C l$, confidence interval; RRT, renal replacement therapy; CVA, cerebrovascular accident; HD, hemodialysis; GI, gastrointestinal; aHR, adjusted hazard ratio; CKD, chronic kidney disease; OR, odds ratio; OAC, oral anticoagulants.

*High risk $\left(\mathrm{CHA}_{2} \mathrm{DS}_{2}-\mathrm{VASc}\right.$ score $\left.\geq 2\right)$.

when compared to warfarin treatment. ${ }^{58}$ In a recent analysis of 16 studies involving 71,877 ESRD patients with AF, authors did not find a decreased risk of CVA/TIA with use of apixaban or warfarin. Mortality risk was much lower with use of apixaban 5 mg when compared to warfarin ( $\mathrm{HR}, 0.65 ; 95 \% \mathrm{Cl}, 0.45$ to 0.93$)$, apixaban $2.5 \mathrm{mg}(\mathrm{HR}, 0.62 ; 95 \% \mathrm{Cl}, 0.42$ to 0.90$)$, and no anticoagulants ( $\mathrm{HR}, 0.61 ; 95 \% \mathrm{Cl}, 0.41$ to 0.90$).{ }^{59} \mathrm{On}$ the other hand, in a retrospective study of 114 ESRD patients on $\mathrm{HD}$, total bleeding events were increased with continuation of apixaban use $(O R, 13.07 ; P=0.018)$, increased total daily dose $(O R, 1.72$; $P=0.003)$, and total dialysis sessions while on apixaban $(O R, 2.04$; $P=0.033){ }^{60}$ Use of other DOACs such as dabigatran and rivaroxaban is also associated with significant risk of bleeding as compared to apixaban. ${ }^{59}$
Randomized controlled trials involving apixaban and warfarin in ESRD/AF are underway (NCT02933697 and NCT02942407) which hopefully will shed more light on appropriate dosage, safety and efficacy of these agents in ESRD. As noted, most of available data pertains to HD patients. There is paucity of dosing, safety and efficacy information on use of DOACs in patients treated with PD and kidney transplantation. In a subgroup analysis, risk of stroke/systemic embolism with apixaban as compared to warfarin treatment was not impacted by choice of modality as $\mathrm{HD}(\mathrm{HR}, 0.85 ; 95 \% \mathrm{Cl}, 0.66$ to 1.09$)$ or $\mathrm{PD}(\mathrm{HR}, 1.26 ; 95 \% \mathrm{Cl}$, 0.57 to 2.82 ; $P$ for interaction between $\mathrm{HD}$ and $\mathrm{PD}=0.36$ ). Also, death risk due to choice of apixaban versus warfarin was not impacted by whether patient on $\mathrm{HD}(\mathrm{HR}, 0.83 ; 95 \% \mathrm{Cl}, 0.70$ to $1.00)$ or $\mathrm{PD}(\mathrm{HR}, 0.98 ; 95 \% \mathrm{Cl}, 0.52$ to 1.83 ; $P$ for interaction be- 
tween $\mathrm{HD}$ and $\mathrm{PD}=0.62$ ). Similar trends were noticed for major bleeding and GI bleeding. ${ }^{57}$ Table 2 summarizes the major studies investigating role of antiplatelet agent as aspirin, vitamin $\mathrm{K}$ antagonist as warfarin and DOAC as apixaban in ESRD patients with $\mathrm{AF}^{4,5,10,43,44,57-59,61-65}$

\section{Conclusions}

ESRD is a complex scenario whereby usual interventions do not often provide desired results as one would observe in the general population. There is a great degree of paradox in how ESRD patients respond to a clinical condition and treatment given. $\mathrm{AF}$ is one such unique co-morbidity which greatly increases the risk of CVA/TIA and mortality. Unfortunately, therapy with antiplatelet agents and systemic anticoagulants do not consistently result in the improved outcomes, instead may add further to the risk of complications. There are concerns, confusion and consequences of each step we take or hold back especially in ESRD patients with $\mathrm{AF}$ regarding the anticoagulation question. Due to the contradictory results and outcomes, it is not possible to argue for or against the use of any given therapeutic agent in particular. Hopefully, data from randomized controlled trials in near future will help us to overcome these challenges and guide us in making well informed clinical decisions.

\section{Disclosure}

Narender Goel has served on nephrology advisory board meeting for Horizon Therapeutics.

\section{References}

1. United States Renal Data System. 2019 USRDS annual data report: epidemiology of kidney disease in the United States. USRDS. https://www.usrds.org/annual-data-report. 2019. Accessed August 12, 2020.

2. United States Renal Data System. 2018 USRDS annual data report: Epidemiology of kidney disease in the United States. USRDS. https://www.usrds.org/annual-data-report. 2018. Accessed August 12, 2020.

3. Buiten MS, de Bie MK, Rotmans JI, Gabreëls BA, van Dorp W, Wolterbeek $\mathrm{R}$, et al. The dialysis procedure as a trigger for atrial fibrillation: new insights in the development of atrial fibrillation in dialysis patients. Heart 2014;100:685-690.

4. Abuhasira R, Mizrakli Y, Shimony A, Novack V, Shnaider A, Haviv YS. Atrial fibrillation characteristics in patients on haemodialysis vs. peritoneal dialysis. Sci Rep 2018;8:2976.

5. Olesen JB, Lip GY, Kamper AL, Hommel K, Køber L, Lane DA, et al. Stroke and bleeding in atrial fibrillation with chronic kidney disease. N Engl J Med 2012;367:625-635.

6. Wanner C, Herzog CA, Turakhia MP; Conference Steering Committee. Chronic kidney disease and arrhythmias: highlights from a Kidney Disease: Improving Global Outcomes (KDIGO) Controversies Conference. Kidney Int 2018;94:231234.

7. Potpara TS, Ferro C, Lip GYH, Dan GA, Lenarczyk R, Mallamaci $F_{1}$ et al. Management of atrial fibrillation in patients with chronic kidney disease in clinical practice: a joint European Heart Rhythm Association (EHRA) and European Renal Association/European Dialysis and Transplantation Association (ERA/EDTA) physician-based survey. Europace 2020;22:496505.

8. Chang $\mathrm{CH}_{\text {, Fan }} \mathrm{PC}$, Lin $\mathrm{YS}$, Chen $\mathrm{SW}$, Lin MS, Wu M, et al. Atrial fibrillation and associated outcomes in patients with peritoneal dialysis and hemodialysis: a 14-year nationwide population-based study. J Nephrol 2020 Feb 21 [Epub]. https://doi.org/10.1007/s40620-020-00713-4.

9. Findlay M, Maclsaac R, MacLeod MJ, Metcalfe W, Sood MM, Traynor JP, et al. The association of atrial fibrillation and ischemic stroke in patients on hemodialysis: a competing risk analysis. Can J Kidney Health Dis 2019;6:2054358119878719.

10. Waddy SP, Solomon AJ, Becerra AZ, Ward JB, Chan KE, Fwu $\mathrm{CW}$, et al. Racial/ethnic disparities in atrial fibrillation treatment and outcomes among dialysis patients in the United States. J Am Soc Nephrol 2020;31:637-649.

11. Wetmore JB, Phadnis MA, Ellerbeck EF, Shireman TI, Rigler SK, Mahnken JD. Relationship between stroke and mortality in dialysis patients. Clin J Am Soc Nephrol 2015;10:80-89.

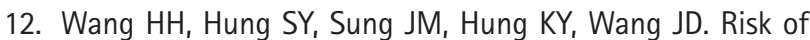
stroke in long-term dialysis patients compared with the general population. Am J Kidney Dis 2014;63:604-611.

13. Malyszko J, Lopatowska P, Mlodawska E, Musialowska D, Malyszko JS, Tomaszuk-Kazberuk A. Atrial fibrillation in kidney transplant recipients: is there a place for the novel drugs? Nephrol Dial Transplant 2018;33:1304-1309.

14. Bansal N, Xie D, Tao K, Chen J, Deo R, Horwitz E, et al. Atrial fibrillation and risk of ESRD in adults with CKD. Clin J Am Soc Nephrol 2016;11:1189-1196.

15. Bansal N, Xie D, Sha D, Appel $\sqcup$, Deo R, Feldman HI, et al. Cardiovascular events after new-onset atrial fibrillation in adults with CKD: results from the Chronic Renal Insufficiency Cohort (CRIC) study. J Am Soc Nephrol 2018;29:2859-2869.

16. Hsu HH, Kor CT, Hsieh YP, Chiu PF. Effects of prevalent and incident atrial fibrillation on renal outcome, cardiovascular events, and mortality in patients with chronic kidney disease. J Clin Med 2019;8:1378. 
17. Tanaka A, Inaguma $D$, Shinjo $H$, Murata $M$, Takeda A; Aichi Cohort Study of Prognosis in Patients Newly Initiated into Dialysis (AICOPP) Study Group. Presence of atrial fibrillation at the time of dialysis initiation is associated with mortality and cardiovascular events. Nephron 2016;132:86-92.

18. Korantzopoulos PG, Goudevenos JA. Atrial fibrillation in endstage renal disease: an emerging problem. Kidney Int 2009;76: 247-249.

19. Chai C, Wang Z, Fan L, Zhang M, Chu Z, Zuo C, et al. Increased number and distribution of cerebral microbleeds is a risk factor for cognitive dysfunction in hemodialysis patients: a longitudinal study. Medicine (Baltimore) 2016;95:e2974.

20. Lau WL, Nunes ACF, Vasilevko V, Floriolli D, Lertpanit L, Savoj $J$, et al. Chronic kidney disease increases cerebral microbleeds in mouse and man. Trans/ Stroke Res 2020;11:122-134.

21. Cho AH, Lee SB, Han SJ, Shon YM, Yang DW, Kim BS. Impaired kidney function and cerebral microbleeds in patients with acute ischemic stroke. Neurology 2009;73:1645-1648.

22. Song TJ, Kim J, Song D, Nam HS, Kim YD, Lee HS, et al. Association of cerebral microbleeds with mortality in stroke patients having atrial fibrillation. Neurology 2014;83:13081315.

23. Charidimou A, Karayiannis $C$, Song TJ, Orken DN, Thijs $V_{1}$ Lemmens $R$, et al. Brain microbleeds, anticoagulation, and hemorrhage risk: meta-analysis in stroke patients with AF. Neurology 2017;89:2317-2326.

24. Lu HY, Liao KM. Increased risk of deep vein thrombosis in end-stage renal disease patients. BMC Nephrol 2018;19:204.

25. Gäckler A, Rohn H, Lisman T, Benkö T, Witzke O, Kribben A, et al. Evaluation of hemostasis in patients with end-stage renal disease. PLoS One 2019;14:e0212237.

26. Jain D, Haddad DB, Goel N. Choice of dialysis modality prior to kidney transplantation: does it matter? World J Nephrol 2019;8:1-10.

27. Parajuli S, Lockridge JB, Langewisch ED, Norman DJ, Kujovich $\mathrm{JL}$. Hypercoagulability in kidney transplant recipients. Transplantation 2016;100:719-726.

28. Mohapatra A, Valson AT, Gopal B, Singh S, Nair SC, Viswabandya $A$, et al. Hemostatic abnormalities in severe renal failure: do they bark or bite? Indian J Nephrol 2018;28:135142.

29. Aursulesei V, Costache II. Anticoagulation in chronic kidney disease: from guidelines to clinical practice. Clin Cardiol 2019;42:774-782.

30. Lutz J, Menke J, Sollinger D, Schinzel H, Thürmel K. Haemostasis in chronic kidney disease. Nephrol Dial Transplant 2014;29:29-40.

31. Kaw D, Malhotra D. Platelet dysfunction and end-stage renal disease. Semin Dial 2006;19:317-322.

32. Chao TF, Liu CJ, Wang KL, Lin YJ, Chang SL, Lo LW, et al. Incidence and prediction of ischemic stroke among atrial fibrillation patients with end-stage renal disease requiring dialysis. Heart Rhythm 2014;11:1752-1759.

33. Wetmore JB, Ellerbeck EF, Mahnken JD, Phadnis M, Rigler SK,

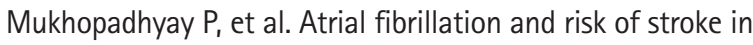
dialysis patients. Ann Epidemiol 2013;23:112-118.

34. Alqahtani F, Berzingi CO, Aljohani S, Al Hajji M, Diab A, Alvi M, et al. Temporal trends in the outcomes of dialysis patients admitted with acute ischemic stroke. J Am Heart Assoc 2018;7: e008686.

35. Gerson LB. Causes of gastrointestinal hemorrhage in patients with chronic renal failure. Gastroenterology 2013;145:895897.

36. Hágendorn R, Farkas N, Vincze Á, Gyöngyi Z, Csupor D, Bajor $J$, et al. Chronic kidney disease severely deteriorates the outcome of gastrointestinal bleeding: a meta-analysis. World J Gastroenterol 2017;23:8415-8425.

37. Wang IK, Cheng YK, Lin CL, Peng CL, Chou CY, Chang CT, et al. Comparison of subdural hematoma risk between hemodialysis and peritoneal dialysis patients with ESRD. Clin J Am Soc Nephro/ 2015;10:994-1001.

38. Sood MM, Garg AX, Bota SE, Marisiddappa L, McArthur E, Naylor $\mathrm{KL}$, et al. Risk of major hemorrhage after kidney transplantation. Am J Nephrol 2015;41:73-80.

39. Holden RM, Harman GJ, Wang M, Holland D, Day AG. Major bleeding in hemodialysis patients. Clin J Am Soc Nephrol 2008;3:105-110.

40. Oladiran 0, Nwosu I. Stroke risk stratification in atrial fibrillation: a review of common risk factors. J Community Hosp Intern Med Perspect 2019;9:113-120.

41. Fox KAA, Lucas JE, Pieper KS, Bassand JP, Camm AJ, Fitzmaurice $\mathrm{DA}$, et al. Improved risk stratification of patients with atrial fibrillation: an integrated GARFIELD-AF tool for the prediction of mortality, stroke and bleed in patients with and without anticoagulation. BMJ Open 2017;7:e017157.

42. Proietti M, Hijazi Z, Andersson U, Connolly SJ, Eikelboom JW, Ezekowitz MD, et al. Comparison of bleeding risk scores in patients with atrial fibrillation: insights from the RE-LY trial. J Intern Med 2018;283:282-292.

43. Chen CY, Lee KT, Lee CT, Lai WT, Huang YB. Effectiveness and safety of antiplatelet in stroke patients with end-stage renal disease undergoing dialysis. Int J Stroke 2014;9:580-590.

44. Bonde AN, Lip GY, Kamper AL, Hansen PR, Lamberts M, Hom-

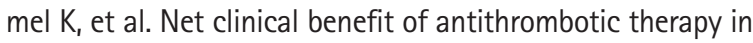
patients with atrial fibrillation and chronic kidney disease: a nationwide observational cohort study. J Am Coll Cardiol 
2014;64:2471-2482.

45. Daimon S, Terai H. Influence of antiplatelet medications on bleeding events in hemodialysis patients. Ther Apher Dial 2011;15:454-459.

46. Aoun M, Koubar SH, Antoun L, Tamim H, Makki M, Chelala D. Reduction of intracerebral hemorrhage in hemodialysis patients after reducing aspirin use: a quality-assurance observational study. PLoS One 2017;12:e0185847.

47. Lemos Cerqueira T, Fartolino Guerrero A, Pérez Fermin CK, Wang $R$, Balbino EE, Breeze $J L$, et al. The use of aspirin to reduce the risk of thrombotic events in patients with endstage renal disease: protocol for a randomized controlled trial. JMIR Res Protoc 2018;7:e10516.

48. Harel Z, Chertow GM, Shah PS, Harel S, Dorian P, Yan AT, et al. Warfarin and the risk of stroke and bleeding in patients with atrial fibrillation receiving dialysis: a systematic review and meta-analysis. Can J Cardiol 2017;33:737-746.

49. Tan J, Liu S, Segal JB, Alexander GC, McAdams-DeMarco M. Warfarin use and stroke, bleeding and mortality risk in patients with end stage renal disease and atrial fibrillation: a systematic review and meta-analysis. BMC Nephrol 2016;17:157.

50. Van Der Meersch H, De Bacquer D, De Vriese AS. Vitamin K antagonists for stroke prevention in hemodialysis patients with atrial fibrillation: a systematic review and meta-analysis. Am Heart J 2017;184:37-46.

51. Lenihan CR, Montez-Rath ME, Shen JI, Scandling JD, Turakhia MP, Chang Tl, et al. Correlates and outcomes of warfarin initiation in kidney transplant recipients newly diagnosed with atrial fibrillation. Nephrol Dial Transplant 2015;30:321329.

52. Mookadam M, Shamoun FE, Mookadam F. Novel anticoagulants in atrial fibrillation: a primer for the primary physician. J Am Board Fam Med 2015;28:510-522.

53. Xarelto (rivaroxaban) prescribing information: package insert. Xarelto. http://www.janssenlabels.com/package-insert/ product-monograph/prescribing-information/XARELTO-pi. pdf. 2020. Accessed August 12, 2020.

54. Eliquis (apixaban) prescribing information: package insert. Eliquis. https://packageinserts.bms.com/pi/pi_eliquis.pdf. 2019. Accessed August 12, 2020.

55. Mavrakanas TA, Samer CF, Nessim SJ, Frisch G, Lipman ML. Apixaban pharmacokinetics at steady state in hemodialysis patients. J Am Soc Nephrol 2017;28:2241-2248.

56. Wang $X$, Tirucherai G, Marbury TC, Wang J, Chang M, Zhang $D$, et al. Pharmacokinetics, pharmacodynamics, and safety of apixaban in subjects with end-stage renal disease on hemodialysis. J Clin Pharmacol 2016;56:628-636.

57. Siontis KC, Zhang X, Eckard A, Bhave N, Schaubel DE, He K, et al. Outcomes associated with apixaban use in patients with end-stage kidney disease and atrial fibrillation in the United States. Circulation 2018;138:1519-1529.

58. Chokesuwattanaskul R, Thongprayoon C, Tanawuttiwat T, Kaewput W, Pachariyanon P, Cheungpasitporn W. Safety and efficacy of apixaban versus warfarin in patients with endstage renal disease: meta-analysis. Pacing Clin Electrophysiol 2018;41:627-634.

59. Kuno T, Takagi H, Ando T, Sugiyama T, Miyashita S, Valentin N, et al. Oral anticoagulation for patients with atrial fibrillation on long-term hemodialysis. J Am Coll Cardiol 2020;75:273285.

60. Steuber TD, Shiltz DL, Cairns AC, Ding Q, Binger KJ, Courtney JR. A multicenter analysis of factors associated with apixabanrelated bleeding in hospitalized patients with end-stage renal disease on hemodialysis. Ann Pharmacother 2017;51:954-960.

61. Shah M, Avgil Tsadok M, Jackevicius CA, Essebag V, Eisen-

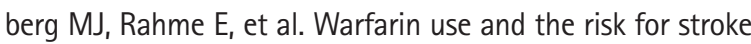
and bleeding in patients with atrial fibrillation undergoing dialysis. Circulation 2014;129:1196-1203.

62. Kai B, Bogorad Y, Nguyen LN, Yang SJ, Chen W, Spencer HT, et al. Warfarin use and the risk of mortality, stroke, and bleeding in hemodialysis patients with atrial fibrillation. Heart Rhythm 2017;14:645-651.

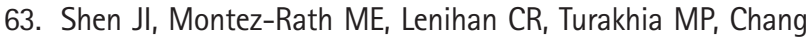
$\mathrm{TI}$, Winkelmayer WC. Outcomes after warfarin initiation in a cohort of hemodialysis patients with newly diagnosed atrial fibrillation. Am J Kidney Dis 2015;66:677-688.

64. Yoon CY, Noh J, Jhee JH, Chang TI, Kang EW, Kee YK, et al. Warfarin use in patients with atrial fibrillation undergoing hemodialysis: a nationwide population-based study. Stroke 2017;48:2472-2479.

65. Mavrakanas TA, Garlo K, Charytan DM. Apixaban versus no anticoagulation in patients undergoing long-term dialysis with incident atrial fibrillation. Clin J Am Soc Nephrol 2020; $15: 1146-1154$ 